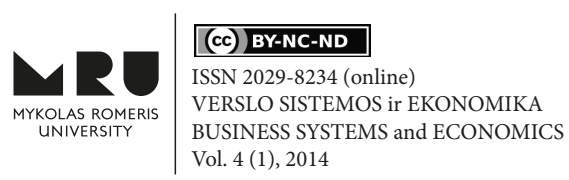

\title{
THE STATE'S DEBT ACCEPTANCE CRITERIA IDENTIFICATION AND EVALUATION OF THEIR ACCEPTABILITY IN LITHUANIA
}

\author{
Žaneta KARAZIJIENĖ \\ Mykolas Romeris University \\ Ateities str. 20, LT-08303 Vilnius, Lithuania \\ E-mail: zkarazijiene@mruni.eu \\ doi:10.13165/VSE-14-4-1-04
}

\begin{abstract}
Debating the introduction of euro in Lithuania, the media and scientific literature have been analysing the rates of economic convergence. This article analyses the stability of the state's financial situation, questions the scientists' attitude towards the state's debt and presents the acceptability criteria of the state's debt. The correspondence of financial situation's stability indicators to acceptance criteria does not get enough attention in scientific works. The aim of this article is to explore the limits of Lithuanian borrowing, using the established criteria for the assessment of state's debt. The evaluation has revealed that the stability indicators of Lithuanian financial situation often do not correspond to the approved criteria. With the use of mathematical modelling, this article calculates the amount of acceptable state's debt during the selected period.
\end{abstract}

Keywords: debt, debt management, budget, deficit, government policy and regulation. JEL Classification: H63, M68.

\section{Introduction}

State's borrowing is a tool of social economic policy. By managing debt, government, first of all, may support certain economic sectors or social groups by entering into indirect obligations, thus achieving its political objectives of the program.

In most of the countries across the world, state's borrowing is considered to be an imminent and irreprehensible phenomenon of economic development. In addition, business development opportunities in many cases depend on greater financial resources that are quite difficult to be formed by using own recourses, especially in developing countries (Kindsfaterienè and Lukaševičius, 2008). When an internal or foreign borrowing is being processed by public sector, capital recourses are being distributed among the countries. Economic theory suggests that government's borrowing may stimulate economic growth. However, there always remains a risk that public debt may become an unbearable burden for country's budget and country's economic development. Thus, country's borrowing is an issue of wide discussions. 
Economic downturn has highlighted a rather different kind of problems in public finance sector. A difficult situation has formed in EU, where a number of euro zone countries are suffering from fiscal imbalances determined by the largest public debt in history. The year of 2009 can be defined as the beginning of public sector's financial problems in this region, when extremely high levels of budget deficit were recorded after the crisis had strongly reduced state revenues and increased costs, thus forcing governments to borrow. Growing debt levels have caused panic in financial markets (Vaicenavičius and Račickas, 2013). Therefore, country's borrowing in the present situation is inevitable, and for this reason its influence towards state's economy should be analyzed.

The essential purpose of public authorities is to ensure economic and political stability (Navickas and Malakauskaitè, 2008). Therefore, in case of limited financial recourses within the countries, the major influence on strengthening their financial systems, by providing the necessary funding, is being done by country's borrowing. Debt management policy is an integral part of country's general economic policy.

Theoretical aspects of public debt and various problematic aspects, related to Lithuania’s borrowing have been discussed in the works of Levišauskaite and Rūškys (2003), Štuopyte and Guzavičius (2008).

Authors of foreign countries discuss country's borrowing rates, reasons and consequences on the basis of their country's experience. It should be noted that the issue of country's borrowing has been emphasized by Mankiw and Taylor (2006), Blanchard (2007), Barro (2008), Krugman (1994, 1998, 2009), Zamkov (1997). On the other hand, these works lack of systematic and generalizing analysis on country's borrowing.

The objective of the article is public debt acceptability criteria.

The aim of the article is to analyze Lithuania’s borrowing acceptability limits by using the defined public debt assessment criteria.

Research methods include the following: systematic and comparative analysis and summary of scientific literature, method of logical deduction, statistical benchmarking analysis, conclusions generation method, mathematical modelling, visualization techniques.

The scientific novelty of the article is reflected in the performed mathematical calculations. In scientific studies, the main focus is given to the prediction of state's debt. This article is a continuation of the previous author's scientific publications. The author previously predicted the possible amount of debt during the selected year or predicted period that was needed to achieve the relevant indicators. Currently, in the published scientific works, little attention has been paid to the analysis of the stability indicators of financial situation, and actually there are no scientific publications that evaluate the stability of state's debt using mathematical modelling. In addition, the article analyses the future, i.e., it evaluates the indicators predicted by the Ministry of Finance. Using this modelling, the possibility to adjust the predicted indicators is highlighted.

\section{Methodological aspects of public debt assessment criteria}

Public debt is one of macroeconomics analysis objects. Public debt is an integral part of state's functions, since the insufficient funding, necessary for state's functions implementation, can be identified as the main cause of public debt. Typically, most countries find their government budget in deficit rather than surplus, so that the amount of worldwide govern- 
ment debt has been growing over time (Frederic, 2012). By assessing the effect of public debt towards the economy, it is necessary to know how public debt is comprehended by different scientists (see Table 1).

Table 1. Concept of public debt, presented by different authors

\begin{tabular}{|l|l|}
\hline \multicolumn{1}{|c|}{ Author } & \multicolumn{1}{c|}{ Concept of public debt } \\
\hline $\begin{array}{l}\text { Public Debt Act } \\
\text { of the Republic of } \\
\text { Lithuania }\end{array}$ & $\begin{array}{l}\text { Public debt - assumed, but not yet implemented obligations by, entitled to } \\
\text { borrow, general government's entities, to repay creditors their funds, which } \\
\text { have been borrowed by distributing Government's securities, by signing loan } \\
\text { agreements, financial lease (leasing) contracts and other debt instruments, } \\
\text { with a consolidated sum. }\end{array}$ \\
\hline $\begin{array}{l}\text { Levišauskaite, K. and } \\
\text { Rūškys, G. (2003) }\end{array}$ & $\begin{array}{l}\text { Public debt is a sum of all issued and uncovered state loans along with accrued } \\
\text { interests that must be paid on fixed time or before the deadline. }\end{array}$ \\
\hline $\begin{array}{l}\text { Snieška, V. et al. } \\
\text { (2005) }\end{array}$ & $\begin{array}{l}\text { Public (government) debt - debt of all government's levels during the financial } \\
\text { year. }\end{array}$ \\
\hline $\begin{array}{l}\text { Mankiw N.G. and } \\
\text { Taylor, P. (2006) }\end{array}$ & $\begin{array}{l}\text { Governments finance budget deficits by borrowing in the bond market, and the } \\
\text { accumulations of past government borrowing is called the government debt. }\end{array}$ \\
\hline Blanchard, O. (2007) & $\begin{array}{l}\text { Public debt is the amount of the reserve - current debt, which government has } \\
\text { accumulated, because of the former deficit. }\end{array}$ \\
\hline $\begin{array}{l}\text { Štuopyté, Ž. and } \\
\text { Guzavičius, A. } \\
\text { (2008) }\end{array}$ & $\begin{array}{l}\text { Public debt is the sum of government's non-refundable loans and unpaid inte- } \\
\text { rests for them, and other financial liabilities that the state has undertaken to its } \\
\text { creditors. }\end{array}$ \\
\hline Barro, J. R. (2008) & $\begin{array}{l}\text { Public debt is the sum of state's debt securities, intended to finance a tempora- } \\
\text { ry lack of funds in the state budget. }\end{array}$ \\
\hline $\begin{array}{l}\text { Buškevičiūté, E. } \\
\text { (2008) }\end{array}$ & $\begin{array}{l}\text { Public debt is specific crediting relationships, emerging among the entities, } \\
\text { residents and state. }\end{array}$ \\
\hline Davulis, G. (2009) & Public debt - the amount of state's total uncovered annual budget deficits. \\
\hline
\end{tabular}
Source: compiled by the author

The definitions of public debt, presented in Table 1, can be divided into two categories. The division can be processed, according to the emphasized subject, describing public debt. Authors, who define public debt as being related to budget imbalance, can be assigned to the first group; while authors, depicting the concept of public debt as the total amount of state's highest authorities' existing loans and their maintenance costs, can be ascribed to the second group. According to such grouping principal, Blanchard, Mankiw and Taylor, Davulis, Barro, and their definitions fall into the first category; and public debt definitions, provided by Levišauskaite and Rūškys, Štuopyte and Guzavičiaus, Buškevičiūte and Snieška, fall into the second one. The national debt is the stock of government bonds outstanding. It is the product of the past and current budget deficits. As the size of the debt increases, the amount of interest that must be paid on the debt tends to rise (Boyes and Melvin, 2008). It is important to accurately determine or predict annual growth rates of country's liabilities, budget deficit and the real GDP growth rates, when assessing debt acceptability. For this reason, the analysis of specific indicators is processed, which helps to assess county's financial stability, cost of funding sources, country's ability to cover liabilities and debt burden scale.

Public debt and its development tendencies are defined by public debt indicators (see Figure 1). Public debt indicators are expressed in absolute units and relative sizes. 
Figure 1. Public debt assessment indicators

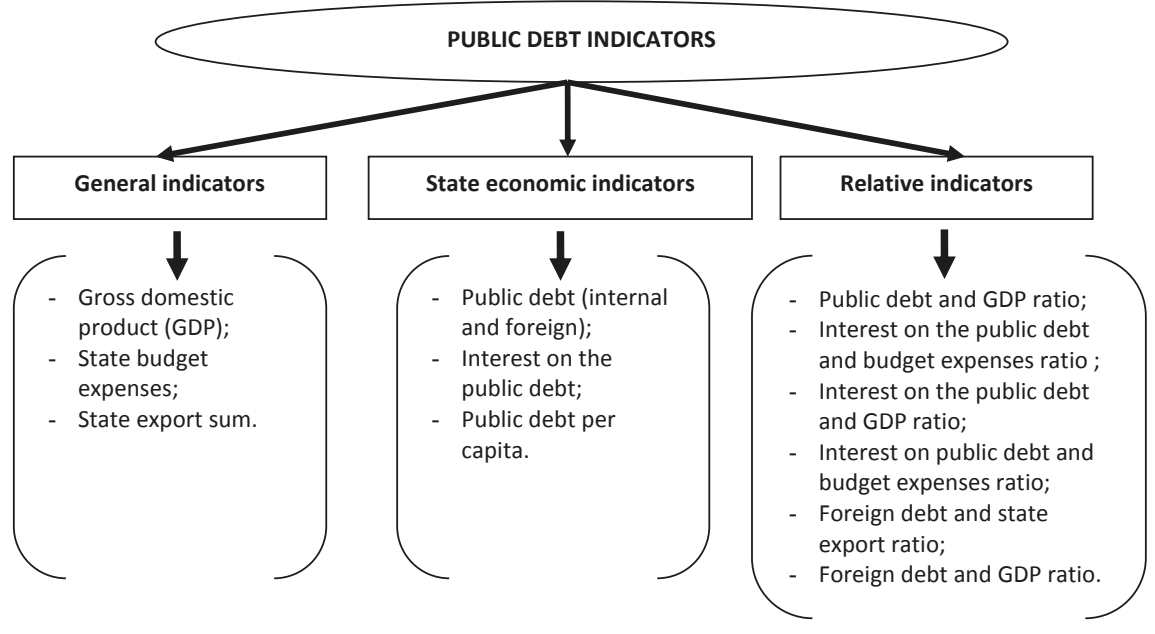

Source: Levišauskaitè and Rūškys (2003)

By applying these indicators, Lithuania's debt condition and alteration can be assessed. Borrowed capital and due to it processed investments grant companies strategic competitiveness. Usually, the lend capital and investments are elements that complement each other: growth of the borrowed capital is determined by investment growth and vice versa (Norvaišienè et al., 2008).

Most of the scientists agree that when economic growth appears and there is a rather small capital and the investment potentiality and its return are higher than in the developed countries, country's borrowing should have a positive effect on economic development. When the amount of government debt relative to the size of the economy gets very large, investors may begin to fear that the government will default on the debt and, by engaging in debt repudiation, fail to pay it all back (Frederic, 2012). The acceptable value of the budget deficit in the long-run is assessed on terms of the ability to keep the variables of the fiscal policy stable. The state offering high interest rates can sell its securities in the short-run, though in case of failure the cost of servicing the national debt will increase in the future, the budget deficit will consequently increase and the government credibility will decrease (Missale et al., 2002). Interest payment constitutes a part of current expenditure of the government, and higher interest payments are to lead either to increased income taxation, or to greater public sector borrowing requirement, which, in its turn, produces even heavier national debt (Colander, 2008).

Assessing theoretically, economic development and growing budget revenues should cover budget deficit and existing public debt. Attempts to assess whether borrowed funds are used effectively and how public debt affects rates of economic growth, employment, inflation and other macroeconomic parameters, lead to disagreements. One of the most prominent economists of our time, Nobel Prize winner in 2008, Krugman (2009) stated that country, being in economic downturn phase, should not be particularly saving, be- 
cause strict saving measures bring country into an even deeper downturn. Such opinion has particularly contradicted other economists' opinion and especially the actions of various countries' governments (including Lithuania's and Latvia's).

In this article, country's borrowing will be assessed, according to public debt indicators provided in Figure 1, for which certain limits, according to Maastricht Treaty or International Monetary Fund requirements (see Table 2), are being determined. On the basis of these criteria, each country's ability to fulfil its debt obligations can be assessed.

Further forming public debt assessment methodology, a possibility to predict country's borrowing limits by using mathematical models is presented. Scientists suggest various mathematical models that may help to assess and predict acceptable size of public debt, referring to present macroeconomic situation in the country. In this article, mathematical models, suggested by Zamkov and Blanchard will be applied.

Table 2. Evaluation criteria of public debt acceptability level

\begin{tabular}{|c|c|c|}
\hline Criteria & Definition of criteria & $\begin{array}{c}\text { Distinguished } \\
\text { acceptability limits }\end{array}$ \\
\hline Public debt and GDP ratio & $\begin{array}{l}\text { Provide country's econo- } \\
\text { mic stability level. }\end{array}$ & $\begin{array}{l}\leq 60 \text { percent GDP } \\
\text { (Maastricht Treaty criteria) }\end{array}$ \\
\hline Foreign debt and GDP ratio & $\begin{array}{l}\text { Country's potentiality to } \\
\text { return debts is assessed. }\end{array}$ & $\begin{array}{l}\leq 30 \text { percent } \\
(\mathrm{IMF})\end{array}$ \\
\hline $\begin{array}{l}\text { Ratio of paid interest on government debt } \\
\text { and government's revenues }\end{array}$ & $\begin{array}{l}\text { The burden of country's } \\
\text { debt is assessed. }\end{array}$ & $\begin{array}{l}\leq 10 \text { percent } \\
\text { (IMF) }\end{array}$ \\
\hline Budget deficit and GDP ratio, $\%$ & $\begin{array}{l}\text { Country's financial si- } \\
\text { tuation is assessed. }\end{array}$ & $\begin{array}{l}\geq 3 \text { percent } \\
\text { (Maastricht Treaty criteria) }\end{array}$ \\
\hline
\end{tabular}

Source: compiled by the author

Acceptable size of public debt in time $t$, according to Blanchards (2007) mathematical model, is determined by the formula No. 1 .

$$
b_{t}=\frac{1+i}{1+\psi} b_{t-1}+p d_{t}+s f_{t}
$$

Here: $b_{t}-$ public debt and GDP ratio in time $t, \%$;

$\psi$ - nominal GDP growth rate, \%;

i - country's borrowing interest norm, \%;

$\mathrm{pd}_{\mathrm{t}}$ - country's initial budget balance and GDP ratio in time $t, \%$;

$\mathrm{sf}_{\mathrm{t}}$ - adjusted ratio of income and cost difference with GDP in time $t, \%$.

Mathematical model for prediction of the relationship between budget deficit, public debt and economic growth rates, suggested by Zamkov (1997), is presented in formula No. 2. The model covers several assumptions:

- the value of the nominal GDP $Y_{t}$ grows at the constant annual rate $p, \%$;

- the total budget deficit (namely, payment in percentage due to the national debt and the main debt) $H_{t}$ annually stands at $q \%$ off GDP;

- the national debt $D_{t}$ (at its nominal value);

- the relation between the national debt and GDP in the year $t\left(d_{t}\right)$. Thus, (Zamkov, 1997): 


$$
\lim _{t \rightarrow \infty} d_{t}=\lim _{t \rightarrow \infty} \frac{D_{t}}{Y_{t}}=\frac{q\left(1+\frac{p}{100}\right)}{p} .
$$

By applying the presented model, the necessary real GDP growth ratio could be calculated in such a manner that the present budget deficit \% GDP and public debt GDP in year $t$ would not have a negative effect on state's economy.

\section{Lithuania's debt criteria assessment and discussion of results}

Public debt at the end of 2012 was equal to 46577, 2 million litas, which constituted 41 percent of gross domestic product (GDP). Public debt ratio with GDP during 2012 increased by 1,6 percentage point (in 2011, it constituted 39,4 percent of GDP) (see Figure 2).

Figure 2. Changes in public debt ratio with GDP in 2008-2012, \%

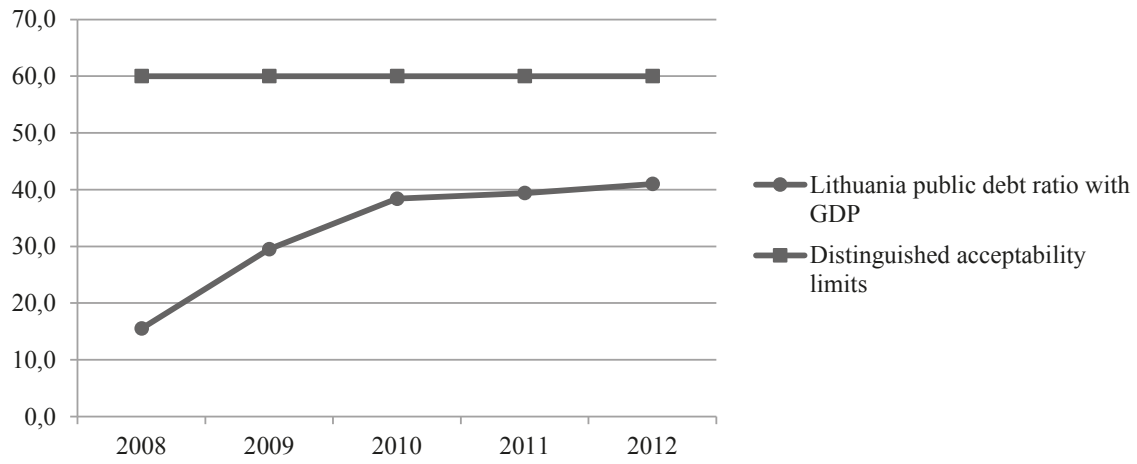

Source: Data of the Lithuanian Ministry of Finance

Since the public sector consists of the central government, local government and state enterprises, the public borrowing requirement can be broken down in the relevant part (Karazijienè, 2013):

- central government borrowing requirement;

- local government borrowing requirement;

- state-owned enterprises borrowing requirements.

At the end of 2012, the central government debt - 43131 million - constituted public debt, local government debt - 2184,5 million litas (out of which 165,5 million litas were state's relent loans on behalf of the state, and 28,1 million litas were short-term loans from state budget) and debt of social security funds - 9727 million litas, out of which 8272 million litas have been on-lend by the Ministry of Finances. Consolidated liabilities between subsectors was 8465,6 million litas (see Table 3). 
Table 3. National debt according to a sector

\begin{tabular}{|l|r|r|r|r|r|r|}
\hline & \multicolumn{2}{|c|}{ 31 December 2010 } & \multicolumn{2}{|c|}{ 31 December 2011 } & \multicolumn{2}{c|}{ 31 December 2012 } \\
\cline { 2 - 7 } & LTL million & \multicolumn{1}{c|}{ \% } & LTL million & \% & LTL million & \multicolumn{1}{c|}{ \% } \\
\hline General government debt & 36606,5 & 100,0 & 41897,2 & 100,0 & 46577,2 & 100,0 \\
\hline Central government debt & 34129,7 & 93,3 & 38504,7 & 91,9 & 43131,2 & 92,6 \\
\hline Debt of social security funds & 1108,1 & 3,0 & 1590,0 & 3,8 & 1455,0 & 3,1 \\
\hline Local government debt $^{*}$ & 1368,7 & 3,7 & 1802,5 & 4,3 & 1990,9 & 4,3 \\
\hline
\end{tabular}

* Data on local government debt are indicated herein in the consolidated form, i.e. less loans issued by the government

Source: Data of the Lithuanian Ministry of Finance

According to the Maastricht Treaty, general budget deficit of the countries, joining the European Union, should not exceed 3\% of GDP $(q)$ and public debt should not exceed $60 \%$ of GDP $\left(d_{t}\right)$. In order to maintain these marginal parameters for a long period, certain real (wanted) GDP growth rate $(p)$ is necessary, which can be found by modifying and applying formula 2 .

$$
\text { Thus : } 0,6=\frac{3\left(\frac{1+p}{100}\right)}{p} ; \text { where } p=5,26 \%
$$

As can be seen, in order to maintain a certain indebtedness level, quite large GDP growth rates are necessary. Assessing the criteria, this indicator is included into the general assessment table (see Table 4), which is formed according to the analysis, presented in methodological part, Table 2 .

Table 4. Assessment criteria of Lithuania's debt level acceptability

\begin{tabular}{|l|r|r|r|r|}
\hline \multirow{2}{*}{ Criteria } & \multicolumn{3}{|c|}{ Years } & \multicolumn{1}{c|}{$\begin{array}{c}\text { Distinguished } \\
\text { acceptability limits }\end{array}$} \\
\cline { 2 - 5 } & $\mathbf{2 0 1 0}$ & \multicolumn{2}{|c|}{$\mathbf{2 0 1 1}$} & \multicolumn{2}{c|}{$\mathbf{2 0 1 2}$} & $\leq 60 \%$ GDP \\
\hline Public debt and GDP ratio & 38,4 & 39,4 & 41 & $\leq 30 \%$ \\
\hline Foreign debt and GDP ratio & 28,3 & 29,1 & 31 & $\leq 10 \%$ \\
\hline $\begin{array}{l}\text { Ratio of paid interest on government debt and } \\
\text { government's revenues }\end{array}$ & 5,6 & 5,7 & 6 & $\leq 3 \%$ \\
\hline Budget deficit and GDP ratio, \% & 7,2 & 5,5 & 3,2 & $\geq 5,26 \%$ \\
\hline Ratio of GDP growth, \% & 1,6 & 6 & 3,7 & \\
\hline
\end{tabular}

Source: Data of the Lithuanian Ministry of Finance, Eurostat

By analysing the assessment criteria of Lithuania's debt level acceptability, it can be distinguished that two criteria, the ratio of public debt and GDP, and the ratio of paid interest on government debt and government's revenues, during the last year did not exceed acceptability limits. However, other criteria exceeded acceptability limits in one or the other year. By analysing ratio of Lithuania's foreign debt and GDP, it can be noted that from 2010 to 2012 the foreign debt was constantly growing, and in 2012 it exceeded the acceptability level by $30 \%$. Budget deficits are financed by public borrowing, which increases the stock of public debt already in existence (Burda and Wyplosz, 2013). The most notable excess of the acceptability level happened during budget deficit and GDP ratio assessment. Although this criterion during the last year was becoming closer to the level of $3 \%$, it still remains difficult to achieve it in Lithuania in an economic sense (see Figure 3). 
Figure 3. Change of budget deficit and GDP in 2008-2012, \%

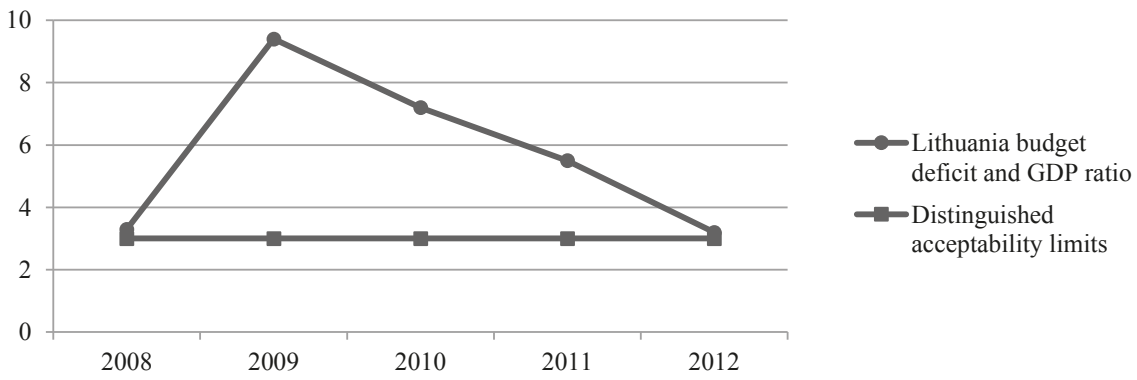

Source: Data of the Lithuanian Ministry of Finance

After assessing Lithuania's public debt acceptability criteria, the prediction of Lithuania's debt and GDP ratio is being processed. Prediction in being processed according to the presented Blanchard's (1) formula and Zamkov's (2) formula. The results are presented in Table 5 .

Table 5. Prediction of public debt and GDP ratio potential levels

\begin{tabular}{|l|r|r|r|r|}
\hline & \multicolumn{1}{|c|}{$\mathbf{2 0 1 2}$} & \multicolumn{1}{|c|}{$\mathbf{2 0 1 3}$} & \multicolumn{1}{c|}{$\mathbf{2 0 1 4}$} & \multicolumn{1}{c|}{$\mathbf{2 0 1 5}$} \\
\hline Public debt and GDP ratio, \% & 40,5 & 39,7 & 41,2 & 39,6 \\
\hline Nominal GDP, \% & - & 5,1 & 6,1 & 7,8 \\
\hline Real GDP, \% & - & 3,4 & 3,6 & 3,9 \\
\hline Initial deficit and GDP ratio, \% & - & 2,5 & 1,5 & 0,5 \\
\hline Long-term interest norm, \% & - & 5,0 & 5,3 & 5,6 \\
\hline $\begin{array}{l}\text { Adjusted ratio of income and cost difference with GDP } \\
\text { in time t }\end{array}$ & - & $0^{*}$ & $0^{*}$ & \\
\hline $\begin{array}{l}\text { Prediction of public debt and GDP ratio possible limits, } \\
\text { according to Blanchard's methodology }\end{array}$ & - & 42,59 & 40,80 & 40,46 \\
\hline $\begin{array}{l}\text { Prediction of public debt and GDP ratio possible limits, } \\
\text { according to Zamkov's methodology }\end{array}$ & - & 30,15 & 28,2 & 25,78 \\
\hline
\end{tabular}

${ }^{*}$ No adjustment has been done in predicting indicators.

Source: compiled by the author

For calculations, macroeconomic indicators, predicted for 2013-2015 by Lithuanian Ministry of Finances - public debt and GDP ratio, \%, nominal and real GDP growth rate, $\%$, initial deficit and GDP ratio, $\%$, long-term interest norm, $\%$, have been used. The aim of this analysis was to assess, whether macroeconomic indicators predicted by the Lithuanian Ministry of Finances will not affect the economy negatively. After the calculations, it was noted that the results varied greatly. Calculations of potential public debt and GDP ratio, according to Blanchard's methodology, presented that debt level during 2013-2015 could be slightly higher, accordingly $2,89 \%$ and $0.86 \%$, while predicted indebtedness of $41,2 \%$ of GDP in 2014 should be lower by $0,4 \%$, whereas calculations, according to Zamkov's methodology, determined that predicted indebtedness during the period of 2013-2015 will be excessive on average by $12 \%$ each year. 


\section{Conclusion}

It should be noted that public debt and its variation tendencies are described by public debt indicators that could be categorized into general, state's economic and relative indicators. These debt indicators can be expressed by absolute units and relative sizes. The state of Lithuania's public debt and its variations can be assessed by applying these indicators.

After Lithuania's debt criteria were assessed, it was determined that the criteria, provided in Maastricht Treaty or approved by International Monetary Fund, were disregarded. Lithuania's foreign debt in 2012 exceeded the acceptability level by $30 \%$ and constituted $31 \%$ of GDP. Budget deficit and GDP ratio during the investigation period in 2010-2012 was in all times excessive, according to the Maastricht Treaty.

Mathematical modelling, used in researches, enabled to reveal Lithuania's debt reliance on budget deficit and real GDP growth rate. A more detailed analysis on the basis of theoretical and practical suggestions, provided in the article, could help in forming country's borrowing policy.

\section{References}

Barro, R.J. (2008). Macroeconomics: A Modern Approach. Thomson South-Western. Blanchard, O. (2007). Makroekonomika. Vilnius: Tyto Alba.

Boyes, W., and Melvin, M. (2008). Macroeconomics. Houghton Mifflin Company. Burda, M., and Wyplosz, Ch. (2013). Macroeconomics: A European Text. Oxford University.

Buškevičiūtè, E. (2008). Viešieji finansai. Kaunas: Technologija.

Davulis, G. (2009). Ekonomikos teorija. Vilnius: Mykolo Romerio universiteto Leidybos centras.

Eurostat. Statistics Database. Retrieved November 20, 2013 from http://epp.eurostat.ec.europa.eu/por$\mathrm{tal} /$ page/portal/statistics/search_database

Frederic, S. (2012). Macroeconomics Policy and Practice. Pearson Education Limited.

Colander, D. C. (2008). Macroeconomics. New York: McGraw-Hill/Irwin.

Karazijienè, $\breve{\text {. }}$ (2013). Valstybès skolinimosi poreikio projektavimo galimybès. Practice and Research in Private and Public Sector - 2013: 3rd International Scientific Conference: Conference Proceedings. April 11-12, Mykolas Romeris University. Vilnius: Mykolo Romerio universitetas, p. 379-387.

Kindsfaterienè, K., and Lukaševičius, K. (2008). The Impact of the Tax System on Business Environment. Inžinerinè Ekonomika [Engineering Economics]. (57): 70-77.

Krugman, P. (2009). The Return of Depression Economics and the Crisis of 2008. W.W. Norton \& Company.

Levišauskaitè, K., and Rūškys, G. (2003). Valstybès finansai. Kaunas: Vytauto Didžiojo universiteto leidykla.

Statistics Lithuania. (2012). General Government Deficit and Debt. Retrieved November 30, 2013 from http://web.stat.gov.lt/en/pages/view/?id=1379\&PHPSESSID= af1a6857adaf29eb5079e0ee38ecfa7b

Lietuvos Respublikos valstybès skolos ịstatymas. Valstybės žinios. 2004, Nr. 4-31.

General Government Debt 2008-2012. Retrieved November 20, 2013 from http://www.finmin.lt/web/ finmin/leidiniai/skola

Mankiw, N.G., and Taylor, P. (2006). Economics. Thomson.

Missale, A.; Giavazzi, F., and Bengino, P. (2002). How Is the Debt Managed? Learning from Fiscal Stabilizations. Scandinavian Journal of Economics. 3(104): 443-469.

Navickas, V., and Malakauskaite, A. (2008). Nauji makroekonominės politikos svertai: klasterių fenomenas. Verslas: teorija ir praktika. 4: 245-252.

Norvaišienė, R.; Stankevičienè, J., and Krušinskas, R. (2008). The Impact of Loan Capital on the Baltic Listed Companies' Investment and Growth. Inžinerine Ekonomika [Engineering Economics]. (2): 40-48. 
Snieška, V. et al. (2005). Makroekonomika. Kaunas: Technologija.

Štuopyte, Ž., and Guzavičius, A. (2008). The Forecast of the State Admissible Borrowing Limits: The Case of Lithuania. Transformations in Business \& Economics. 2(7, 14), Supplement B: 130-142.

Vaicenavičius, T., and Račikas, E. (2013). Valstybès skolos vertinimo teoriniai ir praktiniai aspektai Europos Sąungos šalių kontekste. Ekonomika ir vadyba: aktualijos ir perspektyvos. 1(29): 38-50.

\title{
VALSTYBĖS SKOLOS PRIIMTINUMO KRITERIJŲ IDENTIFIKAVIMAS IR JŲ PRIIMTINUMO LIETUVOJE VERTINIMAS
}

\author{
Žaneta KARAZIJIENE \\ Mykolo Romerio universitetas, Lietuva
}

\begin{abstract}
Santrauka: Svarstant ịvesti eurą Lietuvoje, žiniasklaidoje ir mokslinejje literatūroje analizuojami ekonomikos konvergencijos rodikliai. Šiame straipsnyje analizuojamas valstybès finansinès padèties tvarumas, tiriamas mokslininkų požiūris ị valstybès skolą, pateikiami valstybės skolos priimtinumo vertinimo kriterijai. Finansinès padèties tvarumo rodiklių atitiktis priimtinumo kriterijams nèra pakankamai akcentuojama moksliniuose darbuose. Šio straipsnio tikslas - naudojant nustatytus valstybès skolos vertinimo kriterijus ištirti Lietuvos valstybės skolinimosi priimtinumo ribas. Atliktas vertinimas atskleidè, kad Lietuvos finansinès padèties tvarumo rodikliai dažnai neatitinka patvirtintų kriterijų. Taip pat straipsnyje taikant matematinį modeliavimą apskaičiuotas priimtinas valstybès skolos dydis pasirinktu laikotarpiu.
\end{abstract}

Reikšminiai žodžiai: valstybės skola, skolos valdymas, biudžeto deficitas, vyriausybės politika ir reguliavimas. 